\title{
Resistance and Local Control of American Multicultural Education in the Era of Globalization
}

\author{
Irma Febriyanti \\ American Studies Doctoral Program. The Faculty of Cultural Sciences, Universitas \\ Gadjah Mada, Indonesia \\ Department of English Teaching. Faculty of Language and Arts Education. Universitas \\ PGRI Madiun, Madiun Indonesia \\ e-mail: irma.febriyanti@mail.ugm.ac.id
}

\begin{abstract}
This paper focuses on the process and result of creating a local control and the development of American schools in Newark, New Jersey. Being poor and insecure neighborhoods, Newark also has a 25 percent higher crime rate than the national average in the US which affects the school system, especially to the minorities. A disproportionate impact on minorities happens because of Newark's population is 75 percent Black and Hispanic. As the $3 / 4$ part of the population, the minorities in Newark had not been able to decide their school system based on the locals' needs. As a result, for decades, the education was mired by corruption, crumbling facilities, and low-performing students. There has been a debate about how the residents of Newark may be able to control Newark Public Schools and why they should gain control of their school board. Being able to regain control of its school board means having their rights to education granted: to adapt and experience American education equally. Controlling the school board has been central to Newark public schools since it is the only way to produce school policies. Globalization in education is not only a global movement of cultural influences, but also the framework of U.S. public schools for its multiculturalism as the country develops its public education system. Therefore, the question asked by this paper is that how education policies can be obtained.
\end{abstract}

\section{Keywords}

Newark, local control, American public schools

\section{Introduction}

Citation: Febriyanti. I: Resistance and Local Control of American Multicultural Education in the Era of Globalization. In. D. Ekawati, et al (eds.): Proceeding of The American Studies International Conference 2018, Vol. 2. pp. 71-76. UGM Digital Press Social Sciences and Humanities, Yogyakarta (2019).

Published. May, 2019

Most people in the United States of America are said to enjoy worlds of white power, yet today there are minorities who have won control in several cities with great struggles for so many decades. Newark is one of them and known for the prevalence of its people of color. Newark holds a living legacy of the Black Power Movement that brought African Americans and other minorities to speak up and fight against the perpetuating discrimination in the US. Minorities' struggles in the US illustrates clashing notions of cultural differences between white people and the colored people which also depicts globalization or the trend of growing worldwide (Pieterse, 2009, p. 43). Not only clashing 
or against each other, but cultural differences connects both of them as well. As Lechner and Boli (2000, p. 2) in The Globalization Reader argues that globalization refers to the processes by which more people across large distances become connected in more and different ways.

Globalization has understood as one of the most widely used terms to describe the current state of the world. Not only it entails a wide range of issues and phenomena, but it also has brought into focus the power of culture in this global environment. The importance of local control in this globalization era such as Newark Public Schools in the U.S. dwells on how a global scale may affect national school systems. This global scale of education is not static, as Joel Spring implied that the global scale of education has a constant dynamic of interaction, p. global ideas about school practices interact with local systems while, through mutual interaction, both the local and the global are changed (Spring, 2009, p. 1). Thus, having local control over the state is a great achievement for local citizens to earn their rights to education, especially in Newark which had riots back the American history.

The history of Newark is seen in Kevin Mumford's Newark, p. A History of Race, and Riots in America. Mumford (2007, p. 3) posits the fact that Newark offers a fresh analysis if this urban growth and economic change by exploring the politics of ethnic settlement and cultural recognition alongside a new framework for understanding mobilizations for protest and modes of civic resolution. Despite its location in the highly populated state of New Jersey (population 8,590,300, the ninth largest), Newark as one of the major cities of New Jersey was hit hard by the cycle of deindustrialization that characterized the rust belt across the nation from the 1950s onward (Mumford, 2001, p. 50).

There was an old argument brought up by Mumford (2001) saying that having blacks or minorities such as Latinos, Hispanic, etc. in the city essentially signified disorganization and failure of the city. However, we cannot ignore the fact that Newark's population is 75 percent Black and Hispanic which lead us to another fact that there are children of minorities struggling to attain educational, social and economic equality and equity. In Newark, racism is an integral element of the Newark community (Phillips Jr., 1975, p. 257). To see the current statements and events of racism in Newark, we may trace it back to Bashir Muhammad Akinyele's (2018) statements which elaborate the idea of racism in Newark with his question in the opening of his article, "What are the tools people of color need to use to make it in America?" The question has painful answers for the minorities since they know that people of color have not so many opportunities to be treated equally in their own country.

Akinyele (2018) wrote to Patch.com, online news for the people of Newark, an article entitled "Newark Event, p. Being Black and Brown in America." The article informs about a free program "Real Talk Thursday" which aims to speak and inspire Newark's students, and the community in the city, to help them survive the trappings of community violence, domestic violence, police brutality, self-hatred, white supremacy and racism in their society. This white supremacy has been around for centuries, long enough to create a sturdy system of injustice and one of them is an American school. According to Whitney M. Young (1969) in his "Minorities and Community Control of the Schools" the public schools are so structured that the white middle class is able to exclude the community of the poor and the black from their proportionate share in the responsibility for school decision-making. Young's (1969, p. 285) statements about race disparities may relate to Newark, as "even in the areas where the overwhelming majority of the school population is black, representatives of the black community - as though not only their most powerful, but their only constituent community were the white one."

\section{Theoretical Framework}

This research uses social movement and resistance groups which is a concept that has been continually developed from the 1960s and defined as an interdisciplinary study within the social sciences that generally seeks to explain why social mobilization occurs, the forms under which it manifests, as well as potential social, cultural, and political consequences (Metzger, 2014, p. 1). The social mobilization in here is placed by the resistance of the local people and their struggle in achieving an equal education.

The principles of local identity with diverse aspects contain a variety of local identity features to connect people and the environment, such as physical, social, sensory, and memory (Shao, 2014, p. 140). Hence, local identity in this research refers to all people of Newark who connect themselves with their environment and one of them is their public schools. Public schools give society a start to achieve opportunities ahead in the future. Local identity of Newark is more than just the dominated race in the society, but also how the society lives on their daily basis with their limitations and skills. Poor society will lead to poor students who cannot afford school tools, let alone have an early childhood education for their 
children. Hence, there is some resistance towards schools' standardized tests and curriculums made by Superintendents who do not understand the needs of people in Newark.

Despite flow and network images of globalization regarding education such as a national standard of education. Spring $(2009$, p. 7) revealed that, local officials and teachers do not simply dance to the tune of global flows and networks. There are three options that can be faced by the locals regarding those global scales, p. First, they might give meaning to the influence of global educational policies and practices through the lens of their own cultural perspectives. Second, they might adapt global educational practices to local conditions. And lastly, they might reject or resist global influences.

\section{Methodology}

This research is qualitative research demonstrating an inquiry in which relies on seeing a phenomenon as a text. The data is not about a statistic or numeral account but more on written data such as a transcript, quotation, and other written sources. The primary data are some local events recorded by local and national media about resistance and local control of Newark Public Schools. They are from Huffington Post, NewJersey.com, New York Times, ChalkBeat.org, Fox News, abc7 New York, and CNN which talk about how resistance has happened and they were all solved and managed by the local control of Newark.

The news in this research is seen as the nature of its data which later create better qualitative research for their phenomena (Strauss and Corbin, 1998, p. 19).

\section{$4 \quad$ Results and Discussion}

\subsection{Newark's Quest in Its Own Public Schools, p. The Minority Resistance}

If the dominant community will always be the white one, so do the administrators and practitioners in the Newark Public Schools. Cami Anderson (2011-2015), the superintendent of Newark Public Schools, was the living proof of white domination from the State Board of Education. Anderson was known for her highly controversial reform plan, called "One Newark" plan which expanded school choice in the district and added charter schools Huffington Post, 2015). Valerie Strauss from The Washington Post was one of the medias which report that the public-school system in Newark, New Jersey, is not run by the people of Newark but, rather, by a superintendent appointed by Gov. Chris Christie (R). The complaints about Anderson had come to seven separate complaints of civil rights violations now under investigation by the U.S. Department of Education, Layton reported (Strauss, 2015). Moreover, in 2015, Newark students had been camping out at their school district headquarter for days to ask Anderson meets with them and hears their concerns about how the district being run.

From the students of Newark Public Schools to the Mayor of Newark himself had tried to gain local control over the state. Ras Jua Baraka, the Mayor of Newark, even issued a letter to the Newark community in which he blasts Anderson's reforms, saying in part:

"The facts can no longer be ignored. Our schools are being failed. They are not failing; they are being failed. Our schools have been attacked by a narrow reform agenda that amounts to nothing more than chaos, graft, and miseducation."

Resistance from Baraka and the people of Newark were built up to change how the public schools should be controlled by the local voices, to "restore local control to the Newark Public School System" (Klein, 2015). This resistance promotes social change upon their public schools because Newark Public schools, just like any other schools, are expected to give better opportunities for the children of Newark who could not have enough input from the local voices. They had been demanding to reform its school old system for more than 20 years by state control and superintendent Anderson had turned many "former allies against her as she has implemented a highly controversial 'One Newark' plan" (Strauss, 2015). Not only Anderson's plan closed public schools, expanded charters, and lays off hundreds of teachers, even as they hire hundreds through Teach for America, but also relocated some schools and changed school leadership (Nix, 16 October 2014). On the other hand, people of Newark, especially the students wanted the implementation of an alternative plan, the Newark Promise plan which emphasized local control of the state-run district and 
facility upgrades. The resistance of the students got escalated day by day hoping they can persuade the district as the local voice to reverse course (Huffington Post, 2014).

One of the students' resistance came from the Newark Students Union, Kristin Towkaniuk. Towkaniuk (2014) said union members provided the education leaders with a list of demands that included a call for Anderson's immediate removal, a request that the controversial One Newark school reorganization plan be halted, and demand that students be given an opportunity to help choose the next state-appointed superintendent. Being a city with 75 percent of Black and Hispanic, the people of Newark have always been dissatisfied with the quality of education provided in the public schools for their children. Minorities have been "powerless to determine educational goals and develop strategies toward attaining the goals because they have been forced to accept the decision" made by the larger community (Young, Jr., 1969, p. 285).

The resistance upon Newark Public Schools happened because education deficits colored children in the US and the lack of outrage in response thereto (Paige \& Witty, 2010, p. ix). As demanded by the people of Newark, they proposed a decentralized school system and funds equitably distributed, having the district returned to local control. Baraka, the mayor of Newark, not only had been very supportive during the resistance but also believed Newark Public Schools should be locally controlled. He criticized Anderson through letters to the people of Newark and then to President Obama in 2014, asking the President to intervene in the "disruptive and illegal education reforms" taking place in the school district (Nix, 2014).

Intervention by the local community is not as revolutionary as it sounds. There are facts about white suburbanites who take for granted their control of local school boards and school budgets, in which the white leaders remain the one who enforces the policies of the education system in Newark. In reality, the people of Newark who have been trying to gain control are considered merely to be exercising their constitutional rights. Regardless of decentralization impact pioneered by Baraka, the colored people remain marginalized with few avenues to voice their resistance.

\subsection{Globalization's Effects on Minorities in American Public Schools}

What people of Newark ever wanted was a social change; they created resistance to show the larger community that they promoted local voice to gain stability and opportunities for students in Newark Public Schools. Richard T. Schaefer (2013, p. 402) elaborated that to promote a social change, people tend to create resistance through their efforts. Taken from Schaefer, social change shows significant alteration over time in behavior patterns and culture, including norms and values. As in people of Newark do resistance to change, there is an economic and cultural factor which play important roles as well.

To start the analysis with both economic and cultural factors, first, we have to see schooling as a source of economic improvement and social advancement. Second, being educated is one of the ideas to earn higher opportunities in the future of children, but how is it possible to plan an educational system in a public school with zero experience of its local culture? Joel Spring (2009, p. 201) in his "Globalization of Education" said that culture theorists see the globalization of education as a process originating in the spread of Western educational ideas and sustained by national leaders selecting best practices and research from a global flow of education ideas. Furthermore, Spring (2009) added from the world system and postcolonial/critical perspectives:

\footnotetext{
“...the central figures behind globalization to be those seeking the domination of the rich over the poor or the powerful over the powerless and those resisting this domination. As a result, these theorists contend, globalization is increasing inequalities between and within nations. Rather than considering the globalization of education as a positive spread of Western ideals, like the world education culture theorists, these theorists see it as a continuation of the exploitation by the few of the many. Consequently, the national adoption of an educational reform is often interpreted as another triumph for the power of the rich rather than, as world culture theorists might argue, adoption of a positive idea supported by concepts of justice and school improvement." (p. 201-202)
}

From Spring's idea of educational reform, this paper may see that the educational reform which was a triumph for the power of the larger community is seen through superintendent Cami Anderson and her educational reform in Newark; 'One Newark' plan. Anderson saw her educational reform with the assumption that mass schooling is good for Newark, without considering the possibility that mass schooling might actually be bad or even worse for the minorities and the reform might actually be serving the interest of the majority and powerful and not the interest of the global poor and downtrodden. Anderson's interest, for example, she said the district plans to include private pre-K providers in its universal enrollment system, a new process the district uses in which parents rank their top choice schools and enter a lottery to be placed in one of them. Even as it expands the open enrollment process, Anderson said the district 
seeks to make the student experience at existing charter and public schools more uniform (Nix, 2014). However, a state control under the name of 'uniformity' is not always lead to educational development, it was rather frustrating. To enroll to a public school, one had to apply to be on a waitlist for their preferred school which could make parents with more than one child to put their children in different locations because they could not decide nor choose the public school. Some parents lamented the school where their child was assigned to was inadequate because it was unsafe, under-performing or it would split up siblings.

South Ward councilman John Sharpe James echoed similar sentiments, "The current One Newark Plan and Universal Enrollment Plan will not create excellent schools as proclaimed by state-appointed Superintendent Cami Anderson, the 'One Newark' plan lacks community, lacks transparency and disproportionately affects students of color" (Nix, 2014).

\subsection{Regaining Local Control through Roger León}

Chen (2017) reported through The New York Times, "For more than 20 years, local administrators have had little leverage over the finances or operations of the state's largest school district. Choices about curriculum and programs were made mostly by a state-appointed superintendent, often an outsider. The city could not override personnel decisions:

\footnotetext{
"Local identities are not fixed objects and remnants from the past which only hinder the dynamics of future-oriented policies. Local identities are constantly being shaped and reshaped by different actors, who use local identity discourses not only to hinder but also to promote specific local policies." (Terlow, 2017, p. 1).
}

Local identity represents small-scale places, such as city quarters or street level, to provide features that create a recognizable image of the place and its residents to differentiate from other places. It provides special feelings through physical, social, sensory and memory perspectives; such feelings include both positive and negative emotions (Shao, 2014, p. 56).

\section{Conclusions}

Using social movement theory and resistance groups in this research has explored the phenomenon of social movements transition to become a fully local-controlled public school, with emphasis on the central figures, the superintendents of Newark public schools. Those central figures are the ones who stand behind globalization and claimed to be seeking domination of the rich over the poor or the powerful over the powerless and those resisting this race and class domination. Local resistance can come from the imposition by national governments of education models borrowed from the global flow. Newark public schools are one of the facts that globalization of education as a spread of Western ideals exist. As many world education, culture theorists see it to be a continuation of the exploitation by the few of the many.

\section{References}

1. Chen, D. W. (2017). After More Than 20 Years, Newark to Regain Control of Its Schools. Retrieved 12 September 2017, from https: //www.nytimes.com/2017/09/12/nyregion/20-years-newarkschools-regain-control-baraka.html

2. Klein, R. (2015). These Newark Students Have Been Camping Out at Their School District Headquarters for Days. Retrieved 20 February 2015, from https: //www.huffingtonpost.com/2015/02/20/newark-student-union-sit-in_n_6715860.html

3. Lechner, F. J \& Boli, J. (2000). The Globalization Reader. Chichester: John Wiley \& Sons. p. 2

4. Metzger, T. (2014). "Social Movement Theory and Terrorism: Explaining the Development of AlQaeda "Inquiries journal no. 6 (9), p. 1-4.

5. Mumford, K. (2001). "Double V in New Jersey: African-American Civic Culture and Rising Consciousness Against Jim Crow, 1938-1966." New Jersey History, 119, nos. 3-4 (Fall/Winter), p. 50. 
6. Nix, N. (21 August 2014). Newark Politicians React to 'One Newark' Open Enrollment Process. Retrieved $21 \quad$ August 2014, from https: //www.nj.com/essex/index.ssf/2014/08/community_leaders_react_to_one_newark_open_enroll ment_process.html\#incart_river

7. Nix, N. (16 October 2014). Superintendent: One Newark Plan Will Continue, Expand. Retrieved 16 October 2014, from https: //www.nj.com/essex/index.ssf/2014/10/cami_one_newark_plan_will_continue.html

8. Nix, N. (20 October 2014). Ras Baraka Sends Letter to President Obama Criticizing 'One Newark' School Overhaul. Retrieved 20 October 2014, from https: //www.nj.com/essex/index.ssf/2014/10/baraka_sends_letter_to_president_obama_on_one_new ark.html

9. Paige, R \& Witty, E. (2010). The Black-White Achievement Gap: Why Closing It Is the Greatest Civil Rights Issue of Our Time. New York: Amacom (American Management Association).

10. Phillips, Jr., W. M. (1975). “Educational Policy, Community Participation, and Race.” The Journal of Negro Education, Vol. 44, No. 3, The Continuing Crisis of Urban Education (Summer, 1975), pp. 257267.

11. Pieterse, J.N. (2009). Globalization and Culture: Global Mélange. Maryland: Rowman \& Littlefield Publishers, Inc. pp. 43

12. Shao, Y. (2014). "Local Identity Identification \& Assessment: The Theory, Methodology and Practice of Discovering Local Identity in Yantai, China." Department of Landscape, University of Sheffield, United Kingdom. pp. 40-46

13. Spring, Joel. (2009). Globalization of Education: An Introduction. New York: Routledge. pp. 1-7, 201-202.

14. Strauss, A. L \& Corbin, J. M. (1990) Basics of Qualitative Research: Grounded Theory Procedures and Techniques. California: SAGE Publications. pp. 19

15. Terlow, K. (2017). Local Identities and Politics: Negotiating the Old and the New. New York: Routledge. pp. 1

16. Towkaniuk, K. (2014). NJ Students to 'Escalate' Actions After Demanding Superintendent Cami Anderson's Removal. Retrieved 28 May 2014, from https: //www.huffingtonpost.com/2014/05/28/cami-anderson-newark-studentsunion_n_5404553.html

17. Young, Jr., W. M. (1969). "Minorities and Community Control of the Schools." The Journal of Negro Education, Vol. 38, No. 3, American Minority Groups and Contemporary Education (Summer, 1969), pp. 285-290. 